\title{
Analisis Kepuasan Pelanggan Travel Menggunakan Metode Fuzzy Service Quality
}

\author{
Hesti Sholikah ${ }^{1}$, Syahroni Wahyu Iriananda ${ }^{2}$ \\ 1'hestisholeha@gmail.com, 2 syahroni@widyagama.ac.id
}

Program Studi Teknik Informatika, Fakultas Teknik, Universitas Widyagama Malang

\begin{abstract}
Satria Trans Travel is one of business service that engaged to travel services and car rental. As transportation services provider, Satria Trans Travel need to provide the best service to every customers who need it so that services can continue to grow and can compete in the business world. The method used to measure the quality of service with fuzzy-Servqual method to determine the variable of customer requirement that is not fulfilled by counting gap (gap) between service given with customer expectation as voice of customer. Fuzzy logic is used to estimate the subjectivity of respondents in assigning value to the questionnaire. By using Fuzzy Servqual method, five attributes / criteria are the priority of service quality improvement because it has the highest weighted Servqual (Gap) value. The criteria that are the top priority for service improvement and service quality improvement are the dimensions of Tangibles. The result shows that the negative gap value is -0.912, meaning what is expected according to what customer has not yet got the customer in Travel Satria Trans. The result of calculation of Customer Satisfaction Index (CSI) is $83,76 \%$. Based on the acquisition can be a motivation to continuously improve the quality of service to its customers.
\end{abstract}

Intisari- Travel Satria Trans merupakan usaha yang bergerak dalam bidang jasa travel dan juga rental mobil. Supaya dapat terus berkembang dan dapat bersaing di dunia bisnis Satria Trans perlu memberikan pelayanan yang terbaik kepada pelanggan. Untuk mengukur kualitas pelayanan dapa menggunakan metode metode Fuzzy-Servqual yang digunakan untuk menentukan variabel kebutuhan pelanggan yang tidak terpenuhi dengan menghitung gap (kesenjangan) antara pelayanan yang diberikan dengan harapan pelanggan sebagai voice of costumer. Kriteria yang menjadi prioritas utama untuk diperbaiki dan peningkatan kualitas pelayanan jasa adalah dimensi Tangibles. Hasil penilitian menunjukkan nilai gap negatif adalah $-0,912$, artinya harapan pelanggan masih belum tercapai. Hasil perh itungan Indeks Kepuas an Pelanggan (IKP) sebesar $83,76 \%$. Berdasarkan hasil tersebut dapat dijadikan motivasi untuk terus meningkatkan kualitas pelayanan terhadap pelanggannya.

Kata Kunci: Fuzzy-Servqual, Gap, Quality Service. Indeks Kepuasan Pelanggan (IKP)

\section{PENDAHULUAN}

Seiring berkembangnya teknologi dan informasi di era globalisasi ini telah menimbulkan perubahan yang cukup signifikan akan persaingan usaha pada setiap perusahaan. Sebagai penyedia jasa, Travel Satria Trans harus mampu mempertahankan kualitas pelayanan terhadap pelanggan. Mengingat begitu penting suatu pelayanan bidang jasa yang akan mempengaruhi kuantitas pelanggannya sehingga bisnis dapat terus berjalan. Penilaian kualitas pelayanan sangat penting sehingga dapat membantu bisnis dalam usaha peningkatan kualitas pelayanan yang lebih baik di masa yang akan datang [1].

\section{KAJIAN PUSTAKA}

A. Teori Himpunan Fuzzy

Fungsi keanggotaan fuzzy mempresentasikan derajat kedekatan suatu objek terhadap atribut tertentu sedangkan pada teori probabilitas lebih pada penggunaan frekuensi relat if Adapun alas an logika digunakan antara lain [2][3].

1. Konsep logika fuzzy mudah dimengerti karena konsep matematis yang mendasari penalaran fuzzy sangat sederhana dan mudah dimengerti.

2. Logika fuzzy sangat fleksibel.

3. Logika fuzzy memiliki toleransi terhadap data yang tidak tepat.

4. Dapat membangun dan mengaplikasikan pengalamanpengalaman para pakar secara langsung tanpa harus melalui proses pelatihan

5. Dapat bekerjasama dengan teknik-teknik kendali secara konvensional.

6. Logika fuzzy didasarkan pada bahasa alami.

Kurva segitiga pada dasarnya merupakan gabungan antara 2 garis (lin ier) serta ditandai oleh adanya tiga parameter (a, b, c) yang menentukan koordinat $\mathrm{x}$ dari tiga sudut.

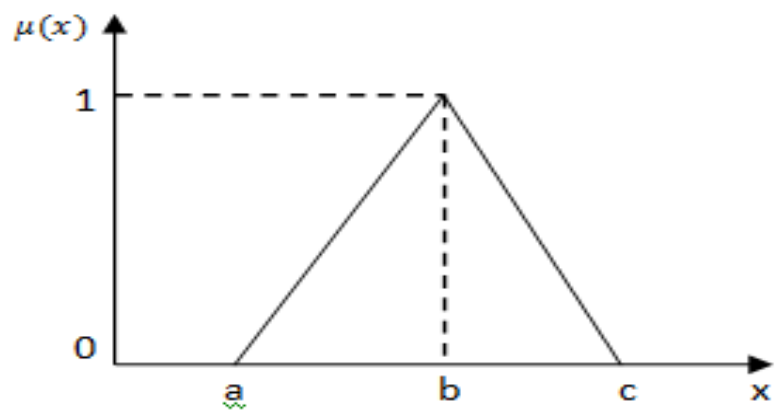

Gambar 1. Grafik fungsi keanggotaan pada representasi kurva segitiga. 
Fungsi keanggotaan ditunjukkan pada persamaan [3] terdapat pada di rumus (1):

$$
\mu(x)=\left\{\begin{array}{l}
0 ; a \leq b / a \geq c \\
\frac{x-a}{b-a} ; a \leq x \leq b \\
\frac{x-c}{b-c} ; a \leq x \leq c
\end{array}\right.
$$

Pada penelitian ini menggunakan fuzzy - Servqual bilangan triangular fuzzy seperti pada gambar 2. untuk merepresentasikan nilai untuk setiap kriteria dari masingmasing alternatif yang akan dipilih [4].

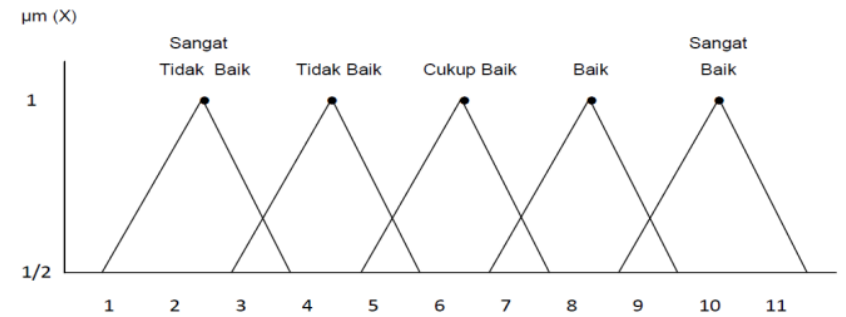

Gambar 2. Bilangan fuzzy untuk penilaian kriteria

\section{B. Kualitas Pelayanan (Service Quality)}

Kualitas jasa (quality service) adalah ukuran seberapa bagus tingkat layanan yang diberikan mampu sesuai dengan ekspektasi pelanggan, dengan tingkat pelayanan yang diberikan secara maksimal akan memberikan kepuasan konsumen. Lima dimensi Service quality meliputi: [5].

1. Bukti langsung (tangible), yang meliputi fasilitas fisik, perlengkapan, pegawai, dan sarana komunikasi.

2. Keandalan (reliability), yakni kemampuan memberikan pelayanan yang dijanjikan dengan segera, akurat, dan memuaskan.

3. Daya tanggap (responsiveness), yaitu keinginan para staf dan karyawan untuk membantu para pelanggan dan memberikan pelayanan dengan tanggap.

4. Jaminan (assurance), yang mencakup pengetahuan, kemampuan, kesopanan, dan sifat yang dapat dipercaya yang dimiliki para staf, bebas dari bahaya, risiko, atau keragu-raguan

5. Empati (emphaty), yang meliputi kemudahan dalam melakukan hubungan, komunikasi yang baik, perhatian pribadi, dan memahami kebutuhan para pelanggan.

\section{Nilai Servqual (GAP)}

Selisih antara persepsi dengan harapan disebut dengan "gap" atau kesenjangan kualitas layanan, yang dirumuskan sebagaiberikut:

$$
\text { Persepsi }- \text { harapan }=\text { gap }
$$

1. Jika gap positif (persepsi > harapan ) maka layanan dikatakan "surprise" dan memuaskan

2. Jika gap nol (persepsi = harapan) maka layanan dikatakan berkualitas dan memuaskan

3. Jika gap negatif (persepsi < harapan ) maka layanan dikatakan tidak berkualitas dan tidak memuaskan [6].

\section{Indeks Kepuasan Pelanggan(IKP)}

Indeks kepuasan pelanggan (IKP) adalah data dan informasi tentang tingkat kepuasan pelanggan yang diperoleh dari hasil pengukuran kuantitatif dan kualitatif atas pendapat pelanggan dalam memperolah pelayanan publik dengan membandingkan antara harapan dan kenyataan [7]

$$
I K P=\frac{T}{D \times Y} \times 100 \%
$$

$\mathrm{T}=$ Total Skor Persepsi $\mathrm{x}$ Harapan pelanggan

$\mathrm{Y}=$ Total nilai Harapan pelanggan

D = Jumlah Dimensi Servqual

\section{E. Kerangka Pemikiran}

Kerangka pemikiran digambarkan pada gambar 3. sebagaiberikut:[7][8].

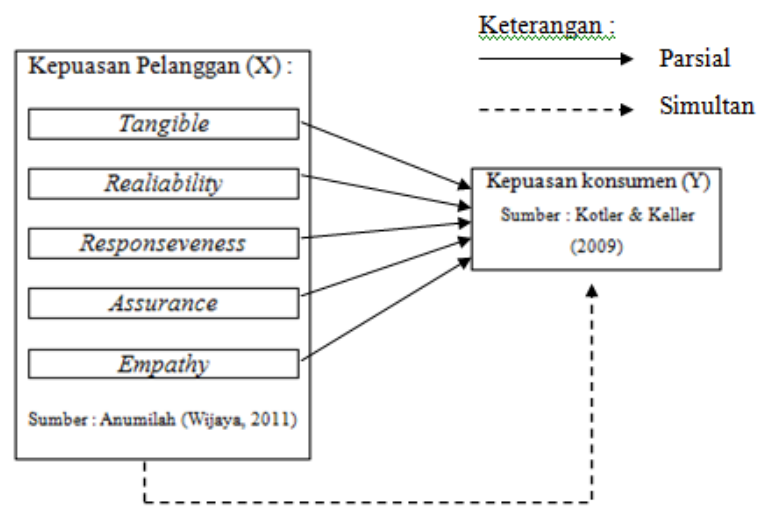

Gambar 3. Kerangka Pemikiran

\section{METODE PENELITIAN}

\section{A. Flowchart Sistem}

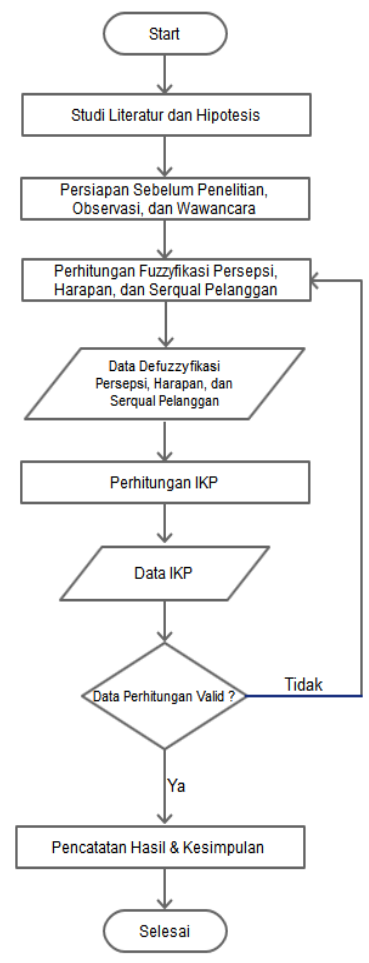

Gambar 4 : Flowchart Sistem

Bagan alir sistem (systems flowchart) merupakan bagan yang menunjukan arus pekerjaan dari sistem secara keseleruhuan. 
B. Diagram Konteks

Berikut ini adalah diagram konteks yang dirancang untuk Travel Satria Trans :

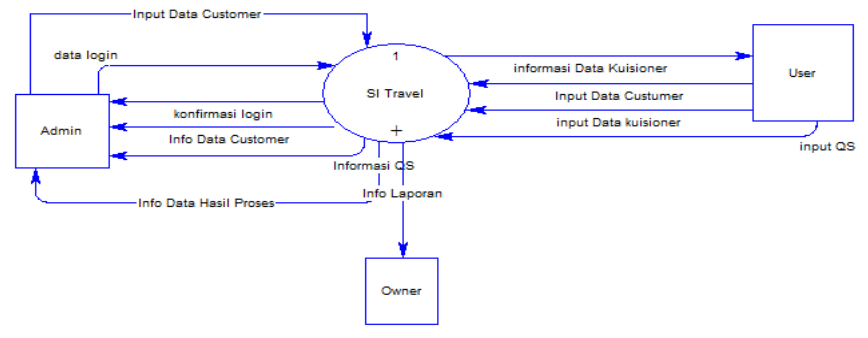

Gambar 5. : Diagram Konteks

\section{ERD (Entity Relationship Diagram)}

Hubungan antara sejumlah entitas yang berasal dari himpunan entitas yang berbeda. Relasi dapat digambarkan sebagaiberikut :

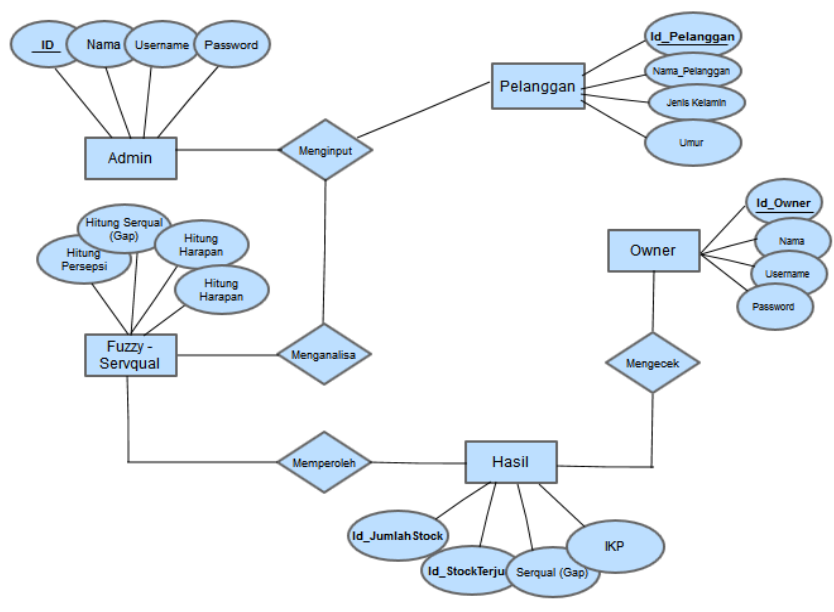

Gambar 8. ERD Sistem

\section{HASIL DAN PEMBAHASAN}

\section{A. Mengintegrasikan Fuzzy-Servqual}

Nilai yang digunakan dalam penentuan bobot (skor) yang kita gunakan untuk mengetahui tingkat kualitas pelayanan (service quality) dari perhitungan nilai fuzzyfikasi adalah sebagaiberikut:

1. Kategori 1 = Sangat Tidak Baik dengan skor $1,2,3,4$ (meliputi jawaban kuesioner Persepsi/Harapan yaitu Sangat Tidak Setuju/ Sangat Tidak Diharapkan).

2. Kategori 2 = Tidak Baik dengan skor 3,4,5,6 (meliputi jawaban kuesioner Persepsi/Harapan yaitu Tidak Setuju/Tidak Diharapkan).

3. Kategori 3 = Cukup Baik dengan skor 5,6,7,8 (meliputi jawaban kuesioner Persepsi/Harapan yaitu Setuju/Cukup Diharapkan).

4. Kategori $4=$ Baik dengan skor $7,8,9,10$ (meliputi jawaban kuesioner Persepsi/Harapan yaitu Setuju/Cukup Diharapkan).

5. Kategori $5=$ Sangat Baik dengan skor $9,10,11,12$ (meliputi jawaban kuesioner Persepsi/Harapan yaitu Sangat Setuju/Sangat Diharapkan)

\section{B. Perhitungan Nilai Fuzzyfikasi/Defuzifikasi}

Dalam menghitung nilai fuzzyfikasi kuesioner persepsi pelanggan dimana nilai fuzzyfikasi merupakan nilai rata-rata dari nilai c, a, b. Perangkingan dilaku kan dari nilai tertinggi ke nilai yang terendah sepertitabel 1 . berikut ini.

Tabel 1.

Hasil Rekapitulasi Data Persepsi Pelanggan sesuai dengan Tingkat Kepentingan

\begin{tabular}{|c|c|c|c|c|c|c|}
\hline No & Kriteria & $\begin{array}{c}\text { Sangat } \\
\text { Tidak } \\
\text { Baik } \\
\text { (1) } \\
\end{array}$ & $\begin{array}{l}\text { Tidak } \\
\text { Baik } \\
\text { (2) }\end{array}$ & $\begin{array}{l}\text { Cuku } \\
\text { p B aik } \\
\text { (3) }\end{array}$ & $\begin{array}{l}\text { Baik } \\
\text { (4) }\end{array}$ & $\begin{array}{l}\text { Sanga } \\
\text { t Baik } \\
\text { (5) }\end{array}$ \\
\hline 1. & $\begin{array}{l}\text { Petugas memberikan } \\
\text { pelayanan secara tepat }\end{array}$ & 1 & 0 & 18 & 53 & 29 \\
\hline 2. & $\begin{array}{l}\text { Kesesuaian pelayanan } \\
\text { dengan janji yang } \\
\text { ditawarkan }\end{array}$ & 0 & 1 & 23 & 54 & 20 \\
\hline 3. & $\begin{array}{l}\text { Petugas memberikan } \\
\text { pelayanan sesuai } \\
\text { dengan waktu yang } \\
\text { dijanjikan }\end{array}$ & 0 & 3 & 12 & 49 & 30 \\
\hline 4. & $\begin{array}{l}\text { Petugas tidak harus } \\
\text { membuat catatan }\end{array}$ & 1 & 3 & 25 & 49 & 32 \\
\hline 5. & $\begin{array}{l}\text { Petugas travel tidak } \\
\text { sigap dalammelayani } \\
\text { pelanggan }\end{array}$ & 0 & 2 & 20 & 52 & 24 \\
\hline 6. & $\begin{array}{l}\text { Petugas dengan cepat } \\
\text { melayani pelanggan }\end{array}$ & 0 & 3 & 34 & 42 & 31 \\
\hline 7. & $\begin{array}{l}\text { Kesediaan petugas } \\
\text { dalam membantu } \\
\text { pelanggan }\end{array}$ & 0 & 0 & 20 & 46 & 45 \\
\hline 8. & $\begin{array}{l}\text { Petugas memberikan } \\
\text { informasi yang jelas } \\
\text { seputar jasa travel }\end{array}$ & 0 & 1 & 17 & 45 & 29 \\
\hline 9. & $\begin{array}{l}\text { Penanganan terhadap } \\
\text { keluhan pelanggan }\end{array}$ & 0 & 2 & 25 & 45 & 26 \\
\hline 10 . & $\begin{array}{l}\text { Petugas mampu } \\
\text { membuat pelanggan } \\
\text { nyaman saat } \\
\text { memberikan } \\
\text { pelayanan }\end{array}$ & 0 & 1 & 19 & 46 & 45 \\
\hline 11. & $\begin{array}{l}\text { Petugas travel tidak } \\
\text { terampil dalam } \\
\text { melayani pelanggan }\end{array}$ & 1 & 1 & 18 & 43 & 29 \\
\hline 12. & $\begin{array}{l}\text { Petugas dapat } \\
\text { menumbuhkan rasa } \\
\text { percaya kepada } \\
\text { pelanggan }\end{array}$ & 0 & 2 & 19 & 50 & 48 \\
\hline 13. & $\begin{array}{l}\text { Petugas tidak mampu } \\
\text { menjawab pertanyaan } \\
\text { pelanggan }\end{array}$ & 1 & 2 & 7 & 60 & 24 \\
\hline 14. & $\begin{array}{l}\text { Kemudahan untuk } \\
\text { menghubungi petugas } \\
\text { travel }\end{array}$ & 0 & 0 & 18 & 49 & 20 \\
\hline 15. & $\begin{array}{l}\text { Petugas mampu } \\
\text { memahami kebutuhan } \\
\text { pelanggan }\end{array}$ & 0 & 4 & 20 & 47 & 25 \\
\hline 16. & $\begin{array}{l}\text { Petugas } \\
\text { memperlakukan } \\
\text { pelanggan dengan } \\
\text { penuh perhatian }\end{array}$ & 0 & 5 & 10 & 46 & 26 \\
\hline 17. & $\begin{array}{l}\text { Petugas dapat } \\
\text { berkomunikasi dengan } \\
\text { baik kepada pelanggan }\end{array}$ & 0 & 1 & 17 & 53 & 25 \\
\hline 18. & $\begin{array}{l}\text { Petugas ramah dan } \\
\text { sopan dalammelayani } \\
\text { pelanggan }\end{array}$ & 0 & 1 & 13 & 52 & 30 \\
\hline 19. & $\begin{array}{l}\text { Ruangan travel bersih, } \\
\text { rapi dan nyaman }\end{array}$ & 0 & 1 & 23 & 46 & 28 \\
\hline 20. & $\begin{array}{l}\text { Penampilan petugas } \\
\text { travel rapi }\end{array}$ & 1 & 2 & 21 & 51 & 21 \\
\hline 21. & $\begin{array}{l}\text { Fasilitas yang } \\
\text { disediakan lengkap } \\
\text { dan memadai }\end{array}$ & 0 & 4 & 33 & 39 & 20 \\
\hline 22. & $\begin{array}{l}\text { Petugas selalu } \\
\text { terampil dalam } \\
\text { mengerjakan tugasnya }\end{array}$ & 0 & 0 & 17 & 57 & 24 \\
\hline
\end{tabular}


Perhitungan nilai fuzzyfikasi data kuesioner dilakukan dengan rumus berikut:

Batas Bawah (c) : $\frac{b_{i 1} * n_{1}+b_{i 2} * n_{2}+b_{i 3} * n_{3}+\cdots+b_{i(k-1)} * n_{k}}{n_{1}+n_{2}+n_{3}+\cdots+n_{k}}$

Nilai Tengah (a) : $\frac{b_{i 1} * n_{1}+b_{i 2} * n_{2}+b_{i 3} * n_{3}+\cdots+b_{i(k-1)} * n_{k}}{n_{1}+n_{2}+n_{3}+\cdots+n_{k}}$

Batas Atas (b) $: \frac{b_{i 2} * n_{1}+b_{i 3} * n_{2}+\cdots+b_{i k} * n_{i(k-1)}+b_{i k} * n_{k}}{n_{1}+n_{2}+n_{3}+\cdots+n_{(k-1)}+n_{j k}}$

Keterangan:

bi $=$ rata-rata nilai fuzzy set per tingkat kepentingan

$\mathrm{n}=$ jumlah responden pertingkat kepentingan

Setelah masing-masing kriteria didapatkan selisihnya, maka pada tahap selanjutnya adalah melakukan defuzzyfikasi untuk mendapatkan suatu nilai tunggal yang representatif dengan menggunakan Arithmatic Mean yang diformulasikan sebagaiberikut :

$$
\mu \mathrm{A} \cap \mathrm{B}=(\mu \mathrm{Ax}+\mu \mathrm{B}[\mathrm{y}]) / 2 .
$$

Berdasarkan perhitungan data persepsi pelanggan dan kemudian di defuzzyfikasikan dengan rumus (7), maka dapat diketahui nilai persepsi tertinggi dari kualitas pelayanan jasa Travel Satria Trans kepada pelanggan adalah "Kesediaan petugas dalam membantu pelanggan" dengan nilai 9,700.

Sedangkan untuk mengetahui kepuasan pelayanan kepada pelanggan, dapat dinilai dari keluhan atau komplain dari pelanggan. Untuk nilai terendah mengenai persepsi adalah "Fasilitas yang disediakan lengkap dan memadai" dengan nilai 8,812 .

Dari hasil pengolahan data harapan pelanggan dan setelah di defuzzyfikasi dapat diketahui nilai harapan tertinggi dari kualitas pelayanan jasa Travel Satria Trans kota Malang kepada pelanggan adalah "Petugas mampu membuat pelanggan nyaman saat memberikan pelayanan" dengan nilai 10.479, seperti yang dikemukakan oleh Pemilik bisnis travel ini.

\section{Perhituangan Nilai Serqual (Gap) Per Kriteria}

Hasil perhitungan nilai servqual (gap) per kriteria dari selisih tingkat persepsi dan harapan menunjukkan sejauh mana pihak manajemen usaha travel telah memberikan pelayanan sesuai dengan keinginan pelanggannya. Peran gap per kriteria akan memberikan tingkat kepentingan seberapa jauh peran kriteria tersebut dalam memberikan Tingkat Kualitas Pelayanan. Berikut ini adalah lima kriteria dengan nilai servqual terbesar yang harus menjadi perhatian Travel Satria Trans, yaitu :

Tabel 2.

Hasil perhitungan nilai servqual (gap)

\begin{tabular}{|c|l|c|c|}
\hline No & \multicolumn{1}{|c|}{ Kriteria } & Serqual & Rank \\
\hline 1 & Penampilan petugas travel rapi & -1.016 & 1 \\
\hline 2 & $\begin{array}{l}\text { Ruangan travel bersih, rapi dan } \\
\text { nyaman }\end{array}$ & -0.922 & 2 \\
\hline 3 & $\begin{array}{l}\text { Fasilitas yang disediakan lengkap } \\
\text { dan memadai }\end{array}$ & -0.892 & 3 \\
\hline 4 & $\begin{array}{l}\text { Petugas ramah dan sopan dalam } \\
\text { melay ani pelanggan }\end{array}$ & -0.880 & 4 \\
\hline 5 & $\begin{array}{l}\text { Petugas dengan cepat melay ani } \\
\text { pelanggan }\end{array}$ & -0.824 & 5 \\
\hline
\end{tabular}

Dari hasil perhitungan nilai servqual (gap) per kriteria diperoleh lima kriteria yang perlu menjadi prioritas untuk dilakukan perbaikan dan peningkatan kualitas pelayanan.

Berdasarkan hasil nilai serqual tersebut, diperoleh hasil yang sesuai dengan informasi pendukung dari pihak manajemen travel, yaitu:

1. Petugas sering melupakan penampilan mereka yang kurang rapi

2. Ruangan travel kurang mendapat perawatan kebersihan

3. Fasilitas yang kurang lengkap dan belum memadai

4. Petugas kurang berkomunikasi dengan ramah kepada pelanggan

5. Petugas kurang cepat dalam melayani pelanggan karena keterbatasan jumlah SDM

\section{Perhitungan Nilai Serqual (Gap) Per Dimensi}

Berdasarkan hasil perhitungan nilai Servqual (gap) per dimensi dari selisih tingkat persepsi dan harapan pelanggan menunjukkan higga sejauh mana pihak manajemen Travel Satria Trans kota Malang telah memberikan pelayanan sesuai dengan keinginan pelanggannya. Peran gap per dimensi akan memberikan tingkat kepentingan seberapa jauh peran kelima dimensi tersebut dalam me mberikan informasi tentang tingkat kualitas pelayanan. Hasilnya dapat dilihat pada tabel 6 . sebagaiberikut:

Tabel 3.

Perhitungan Serqual (GAP) per Dimensi antara Persepsi dan Harapan Pelanggan

\begin{tabular}{|c|c|c|c|c|c|}
\hline $\begin{array}{l}\mathbf{N} \\
\mathbf{0}\end{array}$ & Kriteria & Persepsi & Harapan & Gap & Rank \\
\hline & A.Reliability (Kehandalan) & & & & \\
\hline 1 & $\begin{array}{l}\text { Petugas memberikan } \\
\text { pelayanan secara tepat }\end{array}$ & 9.408 & 10.182 & -0.774 & \\
\hline 2 & $\begin{array}{l}\text { Kesesuaian pelayanan dengan } \\
\text { janji yang ditawarkan }\end{array}$ & 9.148 & 9.877 & -0.729 & \\
\hline 3 & $\begin{array}{l}\text { Petugas memberikan } \\
\text { pelayanan sesuai dengan waktu } \\
\text { yang dijanjikan }\end{array}$ & 9.505 & 9.828 & -0.323 & \\
\hline 4 & $\begin{array}{l}\text { Petugas tidak harus membuat } \\
\text { catatan travel }\end{array}$ & 9.214 & 9.869 & -0.655 & \\
\hline & $\begin{array}{c}\text { Jumlah } \\
\end{array}$ & 9.319 & 9.939 & -0.621 & 4 \\
\hline & $\begin{array}{l}\text { B.Responsiveness (Daya } \\
\text { Tanggap) }\end{array}$ & & & & \\
\hline 5 & $\begin{array}{l}\text { Petugas travel tidak sigap } \\
\text { dalam melayani pelanggan }\end{array}$ & 9.25 & 9.881 & -0.631 & \\
\hline 6 & $\begin{array}{l}\text { Petugas dengan cepat melayani } \\
\text { pelanggan }\end{array}$ & 9.086 & 9.910 & -0.824 & \\
\hline 7 & $\begin{array}{l}\text { Kesediaan petugas dalam } \\
\text { membantu pelanggan }\end{array}$ & 9.7 & 10.3 & -0.6 & \\
\hline 8 & $\begin{array}{l}\text { Petugas memberikan informasi } \\
\text { yang jelas seputar jasa travel }\end{array}$ & 9.467 & 10.058 & -0.591 & \\
\hline 9 & $\begin{array}{l}\text { Penanganan terhadap keluhan } \\
\text { pelanggan }\end{array}$ & 9.189 & 9.75 & -0.561 & \\
\hline & Jumlah & 9.338 & 9.980 & -0.642 & 3 \\
\hline & C.Assurance (Jaminan) & & & & \\
\hline $\begin{array}{l}1 \\
0\end{array}$ & $\begin{array}{l}\text { Petugas mampu membuat } \\
\text { pelanggan nyaman saat } \\
\text { memberikan pelayanan }\end{array}$ & 9.682 & 10.479 & -0.797 & \\
\hline $\begin{array}{l}1 \\
1\end{array}$ & $\begin{array}{l}\text { Petugas travel tidak terampil } \\
\text { dalam melayani pelanggan }\end{array}$ & 9.38 & 9.621 & -0.241 & \\
\hline $\begin{array}{l}1 \\
2\end{array}$ & $\begin{array}{l}\text { Petugas dapat menumbuhkan } \\
\text { rasa percaya kepada pelanggan }\end{array}$ & 9.67 & 10.443 & -0.773 & \\
\hline $\begin{array}{l}1 \\
3\end{array}$ & $\begin{array}{l}\text { Petugas tidak mampu } \\
\text { menjawab pertanyaan } \\
\text { pelanggan }\end{array}$ & 9.463 & 10.019 & -0.556 & \\
\hline & Jumlah & 9.549 & 10.140 & -0.592 & 5 \\
\hline & D. Emphaty (Empati) & & & & \\
\hline $\begin{array}{l}1 \\
4\end{array}$ & $\begin{array}{l}\text { Kemudahan untuk } \\
\text { menghubungi petugas travel }\end{array}$ & 9.296 & 9.9101 & -0.614 & \\
\hline $\begin{array}{l}1 \\
5\end{array}$ & $\begin{array}{l}\text { Petugas mampu memahami } \\
\text { kebutuhan pelanggan }\end{array}$ & 9.187 & 9.759 & -0.572 & \\
\hline $\begin{array}{l}1 \\
6\end{array}$ & $\begin{array}{l}\text { Petugas memperlakukan } \\
\text { pelanggan dengan penuh } \\
\text { perhatian }\end{array}$ & 9.388 & 9.992 & -0.604 & \\
\hline
\end{tabular}




\begin{tabular}{|c|c|c|c|c|c|}
\hline $\begin{array}{l}1 \\
7\end{array}$ & $\begin{array}{l}\text { Petugas dapat berkomunikasi } \\
\text { dengan baik kepada pelanggan }\end{array}$ & 9.375 & 9.929 & -0.554 & \\
\hline $\begin{array}{l}1 \\
8\end{array}$ & $\begin{array}{l}\text { Petugas ramah dan sopan } \\
\text { dalam melayani pelanggan }\end{array}$ & 9.562 & 10.442 & -0.880 & \\
\hline & Jumlah & 9.361 & $\overline{10.006}$ & -0.645 & 2 \\
\hline & $\begin{array}{l}\text { E. Tangibles (Bukti } \\
\text { Langsung) }\end{array}$ & & & & \\
\hline $\begin{array}{l}1 \\
9\end{array}$ & $\begin{array}{l}\text { Ruangan travel bersih, rapi dan } \\
\text { nyaman }\end{array}$ & 9.311 & 10.233 & -0.922 & \\
\hline $\begin{array}{l}2 \\
0\end{array}$ & Penampilan petugas travel rapi & 9.104 & 10.120 & -1.0165 & \\
\hline $\begin{array}{l}2 \\
1\end{array}$ & $\begin{array}{l}\text { Fasilitas yang disediakan } \\
\text { lengkap dan memadai }\end{array}$ & 8.812 & 9.704 & -0.892 & \\
\hline $\begin{array}{l}2 \\
2\end{array}$ & $\begin{array}{l}\text { Petugas selalu terampil dalam } \\
\text { mengerjakan tugasnya }\end{array}$ & 9.393 & 10.209 & -0.816 & \\
\hline & Jumlah & 9.155 & 10.067 & -0.912 & $\mathbf{1}$ \\
\hline
\end{tabular}

Dari hasil perhitungan nilai Servqual (gap) per dimensi, yang menempati ranking pertama adalah dimensi Tangibles sebesar -0.912, seperti halnya pada hasil perhitungan per kriteria dimana tiga kriteria yang menjadi prioritas merupakan bagian dari dimensi Tangibles. Untuk urutan kedua yaitu dimensi Emphaty sebesar -0.645, urutan ketiga yaitu dimensi Responsiveness sebesar -0,642, u rutan keempat yaitu dimensi Reliability sebesar $-0,621$, dan yang terakhir atau urutan kelima yaitu Assurance sebesar-0,592.

\section{E. Perhitungan Nilai Serqual (Gap) Keseluruhan}

Hasil perhitungan nilai Servqual (gap) secara keseluruhan dari selisih tingkat persepsi dan harapan menunjukkan sampai sejauh mana pihak manajemen Travel Satria Trans kota Malang telah memberikan pelayanan sesuai dengan keinginan pelanggannya. Peran gap keseluruhan akan memberikan informasi seberapa besar tingkat kepentingan dan seberapa jauh peran kriteria tersebut dalam tingkat kualitas pelayanan. Hasilnya dapat dilihat pada tabel 7 . berikut ini:

\section{Tabel 4.}

Perhitungan Serqual (GAP) per Dimensi antara Persepsi dan Harapan Pelanggan Keseluruhan

\begin{tabular}{|l|l|l|l|l|l|}
\hline No & Kriteria & Persepsi & Harapan & Gap & Rank \\
\hline 1 & Tangibles & 9.155 & 10.067 & -0.912 & 1 \\
\hline 2 & Emphaty & 9.362 & 10.007 & -0.645 & 2 \\
\hline 3 & $\begin{array}{l}\text { Responsivenes } \\
\text { s }\end{array}$ & 9.338 & 9.980 & -0.642 & 3 \\
\hline 4 & Realibility & 9.319 & 9.939 & -0.621 & 4 \\
\hline 5 & Assurance & 9.319 & 9.939 & -0.621 & 5 \\
\hline & Jumlah & $\mathbf{9 . 2 9 8}$ & $\mathbf{9 . 9 8 6}$ & $\mathbf{- 0 . 6 8 8}$ & \\
\hline
\end{tabular}

Dari hasil perhitungan gap secara keseluruhan menunjukkan bahwa nilai gap negatif yaitu -0,688 yang berarti bahwa apa yang diharapkan pelanggan belum semua sesuai dengan apa yang diperoleh pelanggan di Travel Satria Trans kota Malang.

\section{F. Perhitungan Indeks Kepuasan Pelanggan (IKP)}

Perhitungan IKP diperoleh dari data Defuzzyfikasi antara persepsi dan harapan pelanggan. IKP digunakan untuk mengukur sejauh mana pelanggan merasa puas dengan jasa Travel Satria Trans kota Malang.

Tabel 5.

Perhitungan Indeks Kepuasan Pelanggan (IKP)

\begin{tabular}{|c|c|c|c|c|}
\hline No & Kriteria & $\begin{array}{c}\text { Persepsi } \\
(\mathbf{P}) \\
\text { Skala 1-5 }\end{array}$ & $\begin{array}{c}\text { Harapan } \\
(\mathbf{H}) \\
\text { Skala 1-5 }\end{array}$ & $\begin{array}{c}\text { Skor } \\
(\mathbf{P X H})\end{array}$ \\
\hline 1 & $\begin{array}{l}\text { Petugas memberikan } \\
\text { pelayanan secara tepat }\end{array}$ & 9.408 & 10.182 & 95.795 \\
\hline
\end{tabular}

\begin{tabular}{|c|l|c|c|c|} 
& $\begin{array}{l}\text { Kesesuaian pelayanan } \\
\text { dengan janji yang } \\
\text { ditawarkan }\end{array}$ & 9.148 & 9.877 & 90.358 \\
\hline 3 & $\begin{array}{l}\text { Petugas memberikan } \\
\text { pelayanan sesuai dengan } \\
\text { waktu yang dijanjikan }\end{array}$ & 9.505 & 9.828 & 93.420 \\
\hline 4 & $\begin{array}{l}\text { Petugas tidak harus } \\
\text { membuat catatan travel }\end{array}$ & 9.214 & 9.869 & 90.937 \\
\hline 5 & $\begin{array}{l}\text { Petugas travel tidak sigap } \\
\text { dalam melayani } \\
\text { pelanggan }\end{array}$ & 9.25 & 9.881 & 91.405 \\
\hline 6 & $\begin{array}{l}\text { Petugas dengan cepat } \\
\text { melayani pelanggan }\end{array}$ & 9.086 & 9.910 & 90.046 \\
\hline
\end{tabular}

Besar IKP $=\operatorname{skor} /\left(5^{*} \mathrm{H}\right) \times 100 \%$

$$
\begin{aligned}
& =2061.543 /\left(5^{*} 220.521\right) \times 100 \% \\
& =83.76 \%
\end{aligned}
$$

Dari perhitungan indeks kepuasan pelanggan (IKP) sebesar $83,76 \%$ pelanggan puas akan pelayanan yang diberikan oleh Travel Satria Trans kota Malang namun masih perlu melakukan perbaikan kualitas karena dalam perhitungan nilai servqual (gap) keseluruhan masih menunjukkan nilai negatif $-0,688$ terhadap pelayanan yang diberikan.

\section{KESIMPULAN DAN SARAN}

Dari hasil perhitungan defuzzyfikasi, nilai persepsi tertinggi dari kualitas pelayanan oleh Travel Satria Trans adalah adalah "Kesediaan petugas dalam membantu pelanggan" dengan nilai sebesar 9,700. Sedangkan untuk nilai terendah persepsi pelanggan adalah "Fasilitas yang disediakan lengkap dan memadai" dengan nilai 8,812. Dari hasil perhitungan defuzzyfikasi, nilai harapan tertinggi dari kualitas pelayanan oleh Travel Satria Trans adalah adalah "Petugas mampu membuat pelanggan nyaman saat memberikan pelayanan" dengan nilai 10.479 , dan untuk perolehan nilai terendah yaitu "Petugas travel tidak terampil dalam melayani pelanggan" dengan perolehan nilai sebesar 9.621.

Dari hasil perhitungan serqual (gap) per kriteria dan per dimensi yang memperoleh nilai tertinggi yaitu pada dimensi Tangibles dengan kriteria : penampilan petugas travel rapi, ruangan travel bersih, rapi dan nyaman, dan fasilitas yang disediakan lengkap dan memadai dengan total nilai $-0,912$. Kriteria pada dimensi tangibles dapat dijadikan prioritas dalam meningkatkan kualitas pelayanan jasa travel tersebut. Dari perhitungan indeks kepuasan pelanggan (IKP) sebesar $83,76 \%$ pelanggan puas akan pelayanan yang diberikan oleh Travel Satria Trans kota Malang. Berdasarkan perolehan IKP tersebut dalpat dijadikan motivasi untuk terus meningkatkan kualitas pelayanan terhadap pelanggannya. Informasi yang di dalam website merupakan kegiatan yang terdapat dalam pondok pesantren, dan juga merupakan tempat media dakwah dalam penyampaian kajian - kajian islam berbasis teknolgi.

saran yang dapat diberikan dalam meningkatkan kualitas pelayanannya perlu lebih memperhatikan kerapian petugas dalam melayani pelanggan, sehingga pelanggan merasa senang dan nyaman untuk menggunakan jasa tersebut. Menjaga kebersihan ruangan kerja petugas guna memberikan kenyamanan pada pelanggan yang datang, serta dapat meningkatkan keindahan pemandangan saat berada di ruang kerja. Menambah fasilitas yang dapat menunjang kebutuhan pelanggan saat berada di ruang kerja Travel Satria Trans, misalnya menyediakan fasilitas free wifi untuk pelanggan 
yang sedang menunggu, agar pelanggan tidak merasa bosan berada di ruang tunggu tersebut.

\section{DAFTAR PUSTAKA}

[1] Kotler Philip dan Keller Kelvin Lane. Manajemen Pemasaran (Edisi 13 Jilid 1)., Jakarta: Erlangga, 2009.

[2] Kadek, Ni.,D. Penerapan Fuzzy TOPSIS Untuk Seleksi Penerima Bantuan Kemiskinan. Jurnal Informatika, Vol. 15, No. 2., 2015.

[3] Hanik Rosyidah, Triyastuti.,W.,Agus,.R., Analisis Kualitas Pelayanan Dengan Menggunakan Fuzzy Servqual, Kuadran IPA, Dan Indeks PGCV. Jurnal Gaussian., Volume 4, Nomor 4, Tahun 2015, Halaman 885 - 894. 2015.

[4] Suharyanta Dwi., Analisis Tingkat Kualitas Pelayanan Jasa Menggunakan Metode Service Quality (Servqual) Fuzzy Di Instalasi Radiologi Rumah Sakit Umum Daerah (RSUD) Panembahan Senopati Bantul.,Stikes Surya Global, Yogyakarta. 2012.

[5] Wijaya, Toni., Manajemen Kualitas Jasa Desain Servqual, Qfd, Dan Kano Disertai Contoh Aplikasi Dalam Kasus Penelitian. Jakarta Barat: Pt Indeks., 2010.

[6] Mustofa, M., Handoyo \& Dira,.E., (Analisis Tingkat Kualitas Pelayanan Jasa Dengan Metode Service Quality (Ervqual) Fuzzy Di PT Pos Indonesia Sidoarjo. Jurnal Universitas Upn - Veteran -Jatim. Hal : 1-14., 2011.

[7] Yulis Anggraini., Pengukuran Indeks Kepuasan Pelangan Dengan Pendekatan Partial Least Square (PLS) (Study Kasus : Pelanggan Kartu Im3)., Oktober 2010.

[8] Aminullah, A. \& Abdullah., The Impact Of Baraya Travel's Quality of Services On Customer Satisfaction In Bandung. Universitas Telkom., 2016. 